\title{
Teachers Barriers to Promote Distance Learning in The Era Pandemic Coronavirus Disease (Covid-19)
}

\author{
Sandy Tegariyani Putri Santoso ${ }^{1}$, Wiku Aji Sugiri ${ }^{2}$, Rizki Amelia ${ }^{3}$, Sigit Priatmoko ${ }^{4}$ \\ $\left\{\underline{\text { sandytegariyaniputri@uin-malang.ac.id }}{ }^{1}\right.$, wikusugiri@uin-malang.ac.id ${ }^{2}, \underline{\text { rizkiamelia@uin- }}$ \\ $\underline{\text { malang.ac.id }}^{3}$, $\left.\underline{\text { sigitpriatmoko@uin-malang.ac.id }}^{4}\right\}$ \\ Universitas Islam Negeri Maulana Malik Ibrahim Malang 1,2,3,4
}

\begin{abstract}
The implementation of distance learning during the pandemic has had a significant impact on teachers. This study aims to describe the various teacher barriers to promote distance learning. This study used a survey method with an online questionnaire. The research subjects were teachers at all levels of education. The results showed that most teachers had provided socialization about implementing distance learning to parents and students. The technique of delivering material from the teacher to students' parents is by sending videos or worksheets. Teachers' barriers are related to supporting electronic facilities, parents' educational background, geographical conditions, and signal quality. Although teachers are satisfied with the implementation of distance learning, there is still a great need for continuous socialization for parents regarding implementing distance learning.
\end{abstract}

Keywords: Teacher Barriers; Distance Learning; Covid-19.

\section{Introduction}

At the end of March 2020, the Indonesian government implemented a social distancing policy to reduce the spread of Coronavirus Disease (Covid-19). This policy has a significant influence on the implementation of the education system. Distance learning (DL) is the main alternative in providing learning services. DL can offer students and teachers space to continue to carry out knowledge without direct physical contact [1]. This aims to avoid the threat of massive Covid-19 transmission [2]-[4].

So far, studies on the implementation of DL during the Covid-19 pandemic have tended to address the constraints experienced by students. Several researchers had examined some of these barriers [5] explained a decrease in student motivation when DL was enforced. Students' other barriers are related to supporting electronic devices, such as signal difficulty, limited data quota, slow internet network, and limited gadget ownership [6], [7]. These kinds of situations are more directing students to immediately return to implementing face-to-face learning directly at school [8].

There have not been many studies on the constraints of implementing DL from the teacher's point of view. This aspect is considered necessary because not all teachers are fully prepared to implement DL during a pandemic. Another thing that can be regarded as is the acceptance of teachers in using technological devices.

This article examines the barriers faced by teachers in implementing DL during the Covid19 pandemic. Another aspect that is also described in this article is related to teachers' techniques 
to socialize DL. Furthermore, it will also explain the communication patterns between teachers and parents of students.

\section{Literature Review}

The Covid-19 pandemic has had a significant impact on the education system. Unesco noted that more than 1 billion students were affected by the shift in learning models during the Covid19 pandemic [9]. The implemented DL transformation is considered a responsive response to school closures during the epidemic [10], [11].

Several studies related to DL's implementation explain that teachers, students, and parents faced some barriers. The barriers encountered include the lack of adequate supporting devices to an unstable internet network connection [12]. Furthermore, student learning motivation is currently experiencing a decline [5]. Another problem that arises is related to the technological literacy maturity of all DL actors. Many teachers, students, and parents have not operated technological devices [13], [14].

Specifically, there are several findings that also describe the teacher barriers face in implementing distance learning. Some of these findings are as follows: (a) several parents' gave a complaint to the teachers, they feel burdened by economic, psychological, and social aspects[15]. Many parents stated that DL had demanded that they spend more money to facilitate their children's learning. The simple impact is the increased cost of purchasing internet quotas; (b) Distance learning which should provide a comfortable learning space for students, actually increases the level of saturation[16].and (c) interesting findings also occur in teachers who have to deal with the disability students[17]. Those with disabilities should have the same services in DL during this pandemic. This certainly makes teachers more challenged in carrying out learning.

The number of findings related to these barriers is not an excuse for not providing education services. DL is a learning model that can provide more significant opportunities for teachers and students to communicate and have dialogues or discussions through internet intermediaries [10]. DL can provide time flexibility for students and teachers because they do not always meet physically in the classroom [18]. DL is considered an effort to implement mass education to overcome geographical, socio-economic, and time constraints [19].

Before implementing DL, teachers are expected to analyze various aspects related to the situation of students. For example, the teacher must identify the conditions of the student's family environment. Teachers must have good communication skills with families who will assist students in learning. Since students' environmental conditions significantly affect the success of DL [20].

The teacher must also be able to direct the learning process to be student-centered. Student-centered learning is an approach that can be optimized to increase student participation in the learning process [21]. Students will feel comfortable when given the freedom to express everything related to the material they will study. With various efforts to maximize DL's implementation, it is hoped that the barriers encountered will not become an excessive burden for teachers to facilitate students in learning. 


\section{Research Methods}

This research was conducted through a survey method with the research subjects being teachers at the Early Childhood Education level to Secondary Education as many as 51 people from various Java regions Sumatra and Sulawesi. Data were collected using a questionnaire as the main instrument. The questionnaire was made in the form of a google form so that the reach of respondents was wider and varied. The questionnaire consists of 15 question items that aim to collect information related to the respondents' identity, the forms and media of communication during DL, learning activities carried out during DL, satisfaction with the learning process, and the barriers faced during DL. The questionnaire instrument was first validated by two experts using a questionnaire with an assessment format on a 1-5 scale. Each number in the assessment format is assigned the meaning of $1=$ very unclear, $2=$ less clear, 3 = clear enough, $4=$ clear, and 5 = very clear. To analyze the results of the study by experts, an inter-rater agreement model was used. The expert test index shows a score of 1 , which means that the instrument used is feasible and meets the elements of validity and reliability. The data obtained were then analyzed descriptively.

Table 1. Sample Distribution

\begin{tabular}{ccc}
\hline Early Childhood Education & Elementary School & Secondary School \\
\hline $57 \%(29$ Respondent $)$ & $33 \%(5$ Respondent $)$ & $10 \%$ (17 Respondent $)$ \\
\hline
\end{tabular}

\section{Results and Discussion}

\section{Results}

After the questionnaire was distributed, the results of the data obtained were based on the responses from the respondents, namely as follows:

\subsection{Distance Learning's Socialization}

Implementation of DL is new for all levels of education. Changing the learning system from classical to DL should have required regular socialization so that parents and students are ready to run it. However, it turned out that there were schools that did not conduct socialization related to DL implementation during the pandemic. Data related to schools that carry out socialization can be seen in table 2 .

Table 2. Distance Learning's Socialization

\begin{tabular}{lll}
\hline \multicolumn{1}{c}{ Level of Education } & \multicolumn{1}{c}{ Conduct Socialization } & \multicolumn{1}{c}{ Don't Conduct socialization } \\
\hline Early Childhood Education & $28(96.55 \%)$ & $1(3.45 \%)$ \\
Elementary School & $4(80 \%)$ & $1(20 \%)$ \\
Secondary School & $16(94.12 \%)$ & $1(5.88 \%)$ \\
\hline
\end{tabular}

Based on the table, it can be seen that there are schools that carry out socialization in implementing DL, but there are also schools that do not carry out socialization. At the ECE level $96.55 \%$ carried out socialization and $3.45 \%$ did not carry out socialization. At the elementary 
education level $80 \%$ carry out socialization and $20 \%$ do not implement. At the secondary education level, $94.12 \%$ carried out and $5.88 \%$ did not carry out socialization.

Schools' media to socialize DL include WhatsApp groups, personal chats, circulars letters, social media, parents' meetings, and school websites. The percentage of each platform used for DL-related socialization is shown in table 3.

Table 3. Platform Used for Socialization

\begin{tabular}{lcccccc}
\hline \multirow{2}{*}{$\begin{array}{c}\text { Level of } \\
\text { Education }\end{array}$} & $\begin{array}{c}\text { WhatsApp } \\
\text { Group }\end{array}$ & $\begin{array}{c}\text { Personal } \\
\text { Chat }\end{array}$ & $\begin{array}{c}\text { Written } \\
\text { Letter }\end{array}$ & $\begin{array}{c}\text { Social } \\
\text { Media }\end{array}$ & $\begin{array}{c}\text { Parents } \\
\text { Meeting }\end{array}$ & $\begin{array}{c}\text { School } \\
\text { Website }\end{array}$ \\
\hline $\begin{array}{l}\text { Early } \\
\text { Childhood }\end{array}$ & $26(39.39 \%)$ & $\begin{array}{l}12 \\
(18.18 \%)\end{array}$ & $\begin{array}{l}10 \\
(15.15 \%)\end{array}$ & $8(12.12 \%)$ & $\begin{array}{l}10 \\
(15.15 \%)\end{array}$ & - \\
$\begin{array}{l}\text { Education } \\
\text { Elementary }\end{array}$ & $4(44.44 \%)$ & $1(11.11 \%)$ & $2(22.22 \%)$ & $1(11.11 \%)$ & - & 1 \\
$\begin{array}{l}\text { School } \\
\text { Secondary }\end{array}$ & $16(51.61 \%)$ & $6(19.35 \%)$ & $4(12.90 \%)$ & $4(12.90 \%)$ & - & $1(3.22 \%)$ \\
\hline School & & & & & & $11 \%)$ \\
\hline
\end{tabular}

Based on table 3, it is obtained data that, on the whatsapp group platform used a number of 26 respondents at the early childhood education level, 4 respondents at the elementary education level, and 16 respondents at the secondary education level. Meanwhile, the personal chat platform was used by 12 respondents at the elementary education level, one at the elementary school level, and six respondents at the secondary education level. The written circular platform is also still used in the socialization of distance learning to parents, including 10 respondents at the ECE level, 2 respondents at the elementary education level, and 4 respondents at the secondary education level. While the social media platform, used at ECE level, a total of 8 respondents, primary and secondary education did not use this platform as socialization. Furthermore, socialization through meetings with parents of students is only used at the level of early childhood education, namely in 10 respondents. Finally, the school website is only used by 1 respondent at the elementary education level and 1 respondent at the secondary education level. Thus, it can be concluded that the most widely used platform in carrying out socialization related to distance learning is the whatsapp group, both in early childhood education, basic education, and secondary education.

\subsection{Communication between Teachers and Parents on Distance Learning}

Based on the survey, several communication patterns occur between parents and teachers. Some parents gave feedback after they got DL socialization from the teacher, and some do not. Feedback on socialization is considered a two-way form of communication; meanwhile, no input is one-way communication. A summary of how to communicate between teachers and parents at each level can be seen in Table 4, while the level of fluency is described in Table 5.

Table 4. Kind of Communication between Teacher and Parent

\begin{tabular}{lll}
\hline \multicolumn{1}{c}{ Level of Education } & \multicolumn{1}{c}{ Two Direction } & \multicolumn{1}{c}{ One Direction } \\
\hline Early Childhood Education & $25(86.21 \%)$ & $4(13.79 \%)$ \\
Elementary School & $3(60 \%)$ & $2(40 \%)$ \\
Secondary School & $11(64.71 \%)$ & $6(35.29 \%)$ \\
\hline
\end{tabular}

Although socialization has been carried out, in the process of implementing learning, there are parents who interact with teachers. however, there are also parents who only receive information from the 
teacher without any response from the parents. At the level of early childhood education, 25 respondents carried out two-way communication with their teachers and 4 respondents only carried out one-way communication. Furthermore, at the level of basic education 3 respondents communicate in two directions and 2 respondents only communicate in one direction. While in secondary education 11 respondents communicate two-way with the teacher and 6 respondents carry out one-way communication only, that is, information only comes from the teacher without any parental response.

Table 5. Fluentness of Communication with Parents

\begin{tabular}{llll}
\hline \multicolumn{1}{c}{ Level of Education } & \multicolumn{1}{c}{ Not Fluent } & \multicolumn{1}{c}{ Fluent } & \multicolumn{1}{c}{ Very Fluent } \\
\hline Early Childhood & $24.13 \%$ & $41.38 \%$ & $34.48 \%$ \\
Education & $40 \%$ & $20 \%$ & $40 \%$ \\
Elementary School & $43.53 \%$ & $41.18 \%$ & $35.29 \%$ \\
Secondary School & $23.18 \%$ & \\
\hline
\end{tabular}

one of the things seen from communication is the fluency of communication between teachers and parents. Based on table 5, it can be seen that at the ECE level, 24.13\% of communication is not fluent, $41.38 \%$ is fluent, and $34.48 \%$ is very fluent. At the elementary education level, $40 \%$ are not fluent, $20 \%$ are fluent, and $40 \%$ are very fluent. At the secondary education level, $25.53 \%$ were very fluent, $41.18 \%$ were fluent, and $35.29 \%$ were not. Based on these data, it can still be seen that there are obstacles in communication between teachers and parents.

\subsection{Implementation of Distance Learning}

Some of the media used by teachers to carry out DL include WhatsApp groups, virtual conference platforms such as Zoom or Google Meet, Google Forms \& Quizzes, Google Classrooms, Video Calls, etc. Simultaneously, the material delivery techniques used include sending instructional videos, using print worksheets, using online worksheets such as google forms, and sending video links to parents of students.

Table 6. Platform Used for Distance Learning

\begin{tabular}{lcccccc}
\hline \multirow{2}{*}{$\begin{array}{c}\text { Level of } \\
\text { Education }\end{array}$} & $\begin{array}{c}\text { WhatsApp } \\
\text { Group }\end{array}$ & $\begin{array}{c}\text { Virtual } \\
\text { Conference }\end{array}$ & $\begin{array}{c}\text { Google } \\
\text { Form }\end{array}$ & $\begin{array}{c}\text { Google } \\
\text { Classroom }\end{array}$ & Video Call & Others \\
\hline $\begin{array}{l}\text { Early } \\
\begin{array}{l}\text { Childhood } \\
\text { Education }\end{array}\end{array}$ & $20(68.97 \%)$ & $4(13.79 \%)$ & - & $1(3.44 \%)$ & $2(6.89 \%)$ & $2(6.89 \%)$ \\
$\begin{array}{l}\text { Elementary } \\
\text { School }\end{array}$ & $1(20 \%)$ & - & $4(80 \%)$ & - & - & - \\
$\begin{array}{l}\text { Secondary } \\
\text { School }\end{array}$ & $11(64.71 \%)$ & $1(5.88 \%)$ & - & $3(17.64 \%)$ & - & 2 \\
\hline
\end{tabular}

The platforms used to deliver activity materials or learning media include the WhatsApp group of 32 respondents $(62.7 \%)$, virtual meeting applications such as zoom, googlemeet by 5 respondents (9.8\%), google form \& google quiz as many as 4 respondents $(7,8 \%)$, google classroom as many as 4 respondents (7.8\%), video calls as many as 2 people (3.9\%), and as many as 4 respondents $(7.8 \%)$ using other media.

Table 7. Material Delivery Technique

Level of
Education Material Delivery Technique




\begin{tabular}{lllll}
\hline & $\begin{array}{c}\text { Sending Video } \\
\text { Link }\end{array}$ & $\begin{array}{c}\text { Sending } \\
\text { worksheet paper } \\
\text { to parents }\end{array}$ & $\begin{array}{c}\text { Sending online } \\
\text { worksheet }\end{array}$ & \multicolumn{1}{c}{$\begin{array}{c}\text { Sending Video to } \\
\text { Parents }\end{array}$} \\
\hline $\begin{array}{l}\text { Early } \\
\text { Childhood }\end{array}$ & $6(13.95 \%)$ & $15(34.88 \%)$ & $4(9.30 \%)$ & $18(41.86 \%)$ \\
$\begin{array}{l}\text { Education } \\
\text { Elementary }\end{array}$ & $2(25 \%)$ & - & $5(62.5 \%)$ & $1(12.5 \%)$ \\
$\begin{array}{l}\text { School } \\
\text { Secondary } \\
\text { School }\end{array}$ & $1(5.88 \%)$ & - & $15(88.23 \%)$ & $1(5.88 \%)$ \\
\hline
\end{tabular}

Various ways are used by teachers to convey material to students in addressing DL. These methods include using online worksheets such as google form / google sheet used by 24 respondents $(47.1 \%)$, sending learning videos to students as many as 20 respondents $(39.2 \%)$, sending printed worksheets to parents as many as 15 respondents $(29.4 \%$, and finally by sending a video link that can be accessed via youtube as many as 10 respondents (19.6\%).

Based on the table, it can be concluded that the WhatsApp group is the dominant platform used at the ECE and secondary levels. Meanwhile, at the Elementary Education level, it can be seen that google form is widely used. Meanwhile, in the material delivery technique, sending videos to parents is a technique practiced mainly by teachers at all levels.

\subsection{Teacher's Satisfaction and Barrier of Distance Learning Implementation}

In general, teachers are satisfied with the implementation of distance learning. The level of teacher satisfaction is described in table 8 .

Tabel 8. Teachers Satisfaction Level of Distance Learning Implementation

\begin{tabular}{llll}
\hline \multicolumn{1}{c}{ Level of Education } & \multicolumn{1}{c}{ Not Satisfied } & \multicolumn{1}{c}{ Satisfied } & \multicolumn{1}{c}{ Very Satisfied } \\
\hline Early Childhood & $7(24.14 \%)$ & $12(41.38 \%)$ & $10(34.48 \%)$ \\
Education & & & \\
Elementary School & $1(20 \%)$ & $2(40 \%)$ & $1(20 \%)$ \\
Secondary School & $7(41.17 \%)$ & $8(47.06 \%)$ & $2(11.76 \%)$ \\
\hline
\end{tabular}

In the DL implementation process that occurred during the Covid-19 pandemic, 27 teachers $(52.9 \%)$ were quite satisfied, $9(17.6 \%)$ were satisfied, $2(3.9 \%)$ were very satisfied, 9 $(17.6 \%)$ felt less satisfied, 4 people $(7.8 \%)$ felt very dissatisfied. This is related to the smooth process of communication between teachers and parents/guardians. Based on the results of a survey conducted, only 1 person $(2 \%)$ had very smooth communication with parents/guardians, 17 people $(33.3 \%)$ had smooth communication, 20 people $(39.2 \%)$ were quite fluent, 9 people $(17,6 \%)$ answered not fluently, and 4 people $(7.8 \%)$ answered very not fluently.

Some of the barriers experienced by teachers in DL work include the busyness of parents, the availability of infrastructures such as smartphone ownership, internet quotas, signals, and parent contact numbers that are not known by the teacher, the geographic condition, parents' education level, the illiteracy of parents and lack technology acceptance from the teachers and parent's side; it is also a barrier in implementing DL. Other barriers include parental concern with the implementation of the teaching and learning process. Parents who have more than one child find it challenging to allocate time to accompany their children. 


\section{Discussion}

One of the government's efforts to respond to the Covid-19 pandemic is to close schools for all levels. Distance learning (DL) is the main alternative for implementing continuous learning without having physical contact between teachers and students [1]. The implementation of DL, which is relatively new, requires socialization. DL socialization activities to students and parents aim to optimize learning activities so that learning objectives can still be achieved. Participation and interaction between teachers and parents, and students will determine the direction and success of achieving educational goals [20], [22].

Based on the survey results, communication between teachers and parents has been running. The communication carried out is related to the socialization of DL implementation, the provision of material, and the evaluation process of student learning activities. WhatsApp groups are the primary choice for teachers to convey information because they are considered a medium with a broad reach and easy to use. However, it is not rare to find that there was still one direction communication from the teacher who does not fully involve parents. As a result, communication does not run smoothly, and the learning objectives are not achieved.

Communication media is an essential part of implementing DL. Smartphones are the primary media chosen by teachers in the learning process. At the same time, the WhatsApp application is a platform that is often used through chat features, video sharing, video calls, and sharing links to learning materials. Based on research findings by Asongu \& Odhiambo shows that the use of smartphones makes learning activities more efficacious [23]. Besides, on smartphones, various kinds of applications can support learning activities, such as YouTube, Khan Academy, Pinterest, and other applications that parents and teachers can use to support student learning [24], [25].

The teacher's role in implementing DL is still the same as in classical learning, namely as a facilitator and motivator. However, the approach used by the teacher will determine the success of implementing DL. Student-centered learning (SCL) is an approach that teachers can use to increase student participation in the learning process [21]. The interaction between teachers and students through various online meeting applications, assessment forms, and virtual classes still does not describe SCL implementation. Teachers still use the platform to deliver activity materials to move the teacher's position from classical to virtual. Teachers play more roles as instructors in the learning process, placing students as learning objects and parents as main facilitators in learning activities.

Distance learning requires teachers to design meaningful learning activities that allow students to improve creative thinking and provide education that focuses on enhancing skills and character building in students. In implementing DL, teachers need to improvise in the process of planning and implementing learning. The teacher must identify the source of knowledge and the conditions of the student's family environment. This is necessary because students' environmental conditions significantly affect the success of DL [20]. Not all students make it possible to learn online; thus teachers, still provide worksheet papers as an alternative so that learning objectives can even be achieved.

As something new, DL isn't relatively as smooth as ever. The survey results showed that more than $50 \%$ of respondents just felt quite satisfied. One of the satisfaction indicators used is the level of fluency in communication between teachers and parents. Indonesia's varied geographical conditions are one of the barriers to implementing DL. Several areas do not have internet access. Educational background and economy are also inhibiting factors for DL. Parents' experiences also have an impact on children's learning outcomes. This is correlated with parenting styles and facilities obtained by children in supporting their education [26]. 
Parent involvement in implementing DL is another barrier experienced by teachers. However, parental guidance is needed in implementing DL, especially in technology [27]. The background of parents with low education (even illiteracy) impacts the ability to master technology. Some parents also have difficulty assisting their children because they have to work. Some parents who have more than one child and are at different school levels also become barriers to implementing DL. Besides, the most challenging problem is the apathy of parents towards children's education.

\section{Conclusion}

Distance learning which is applied during the pandemic is a new pattern for Indonesia's education system. One of the steps to optimize DL is by conducting socialization with students and parents. By utilizing various media platforms, teachers can establish good communication in carrying out socialization. However, it turns out that, in general, the teachers are still not satisfied with the implementation of DL due to communication barriers that occur. Among them are the parents' activities, the availability of infrastructure, geographical conditions, the educational background of the parents, and the acceptance of technology from both parents and teachers. Therefore, it is hoped that there will be training that will focus on the theoretical aspects of DL and explain the practical aspects of DL. The DL-related activity should involve teachers and need parents' participation, so they also understand the learning process of their children. Besides, in the future, further research is required related to parental involvement in DL and solutions to overcome communication problems between teachers and parents.

\section{References}

[[1] R. Deng, P. Benckendorff, and D. Gannaway, 'Progress and new directions for teaching and learning in MOOCs', Computers \& Education, vol. 129, pp. 48-60, Feb. 2019, doi: 10.1016/j.compedu.2018.10.019.

[2] L. Hewi and L. Asnawati, 'Strategi Pendidik Anak Usia Dini Era Covid-19 dalam Menumbuhkan Kemampuan Berfikir Logis', JO, vol. 5, no. 1, p. 158, May 2020, doi: 10.31004/obsesi.v5i1.530.

[3] R. H. Syah, 'Dampak Covid-19 pada Pendidikan di Indonesia: Sekolah, Keterampilan, dan Proses Pembelajaran', SJSBS, vol. 7, no. 5, Apr. 2020, doi: 10.15408/sjsbs.v7i5.15314.

[4] P. Wahyono, H. Husamah, and A. S. Budi, 'Guru profesional di masa pandemi COVID-19: Review implementasi, tantangan, dan solusi pembelajaran daring', JPPG, vol. 1, no. 1, Art. no. 1, Apr. 2020, doi: 10.22219/jppg.v1i1.12462.

[5] A. Cahyani, I. D. Listiana, and S. P. D. Larasati, 'Motivasi Belajar Siswa SMA pada Pembelajaran Daring di Masa Pandemi Covid-19', IQ, vol. 3, no. 01, pp. 123-140, Jul. 2020, doi: 10.37542/iq.v3i01.57.

[6] I. A. Jariyah and E. Tyastirin, 'Proses dan Kendala Pembelajaran Biologi di Masa Pandemi Covid-19: Analisis Respon Mahasiswa', Jurnal. Penelitian. Pengkajian. Pendidikan. e-Saintika, vol. 4, no. 2, p. 183, Jul. 2020, doi: 10.36312/e-saintika.v4i2.224.

[7] N. A. Yensy, 'Efektifitas Pembelajaran Statistika Matematika melalui Media Whatsapp Group Ditinjau dari Hasil Belajar Mahasiswa (Masa Pandemik Covid 19)', 2020.

https://ejournal.unib.ac.id/index.php/jpmr/article/view/11410 (accessed Apr. 27, 2021). 
[8] A. Susilo and A. Sofiarini, 'Pembelajaran Sejarah Online Mahasiswa STKIP PGRI Lubuklinggau di Masa Pandemik Covid 19', Kaganga:Jurnal Pendidikan Sejarah dan Riset Sosial-Humaniora, vol. 3, no. 1, pp. 24-32, Jun. 2020, doi: 10.31539/kaganga.v3i1.1303.

[9] Unesco, 'Education: From disruption to recovery', UNESCO, Mar. 04, 2020.

https://en.unesco.org/covid19/educationresponse (accessed Aug. 14, 2020).

[10] M. Bušelić, 'Distance Learning - concepts and contributions', oec, vol. 2, no. 1, Feb. 2017, doi: 10.15291/oec.209.

[11] E. M. Mulenga and J. M. Marbán, 'Is COVID-19 the Gateway for Digital Learning in Mathematics Education?', CONTEMP EDUC TECHNOL, vol. 12, no. 2, p. ep269, Apr. 2020, doi: $10.30935 /$ cedtech/7949.

[12] W. Sari, A. M. Rifki, and M. Karmila, 'ANALISIS KEBIJAKAN PENDIDIKAN TERKAIT IMPLEMENTASI PEMBELAJARAN JARAK JAUH PADA MASA DARURAT COVID 19’, JURNAL MAPPESONA, vol. 2, no. 2, Art. no. 2, Mar. 2020, Accessed: Aug. 14, 2020. [Online]. Available: https://jurnal.iain-bone.ac.id/index.php/mappesona/article/view/830

[13] N. F. Azzahra, 'Mengkaji Hambatan Pembelajaran Jarak Jauh di Indonesia di Masa Pandemi Covid-19’, May 2020, Accessed: Aug. 14, 2020. [Online]. Available: https://repository.cipsindonesia.org/publications/309163/mengkaji-hambatan-pembelajaran-jarak-jauh-di-indonesia-dimasa-pandemi-covid-19

[14] Z. Zaharah and G. I. Kirilova, 'Impact of Corona Virus Outbreak Towards Teaching and Learning Activities in Indonesia', SJSBS, vol. 7, no. 3, Mar. 2020, doi: 10.15408/sjsbs.v7i3.15104.

[15] D. Lase, A. Ndraha, and G. G. Harefa, 'Persepsi Orangtua Siswa Sekolah Dasar di Kota Gunungsitoli Terhadap Kebijakan Pembelajaran Jarak Jauh pada Masa Pandemi Covid-19', SUNDERMANN J. Ilm. Teol. Pendidik. Sains Hum. dan Kebud., vol. 13, no. 2, pp. 85-98, Dec. 2020, doi: 10.36588/sundermann.v13i2.46.

[16] M. Muhammad, F. Setiawan, and n K. D. A. Afiani, 'ANALISIS PROSES PEMBELAJARAN DALAM JARINGAN (DARING) MASA PANDEMI COVID-19 PADA GURU SEKOLAH DASAR MUHAMMADIYAH SE-KOTA SURABAYA', Syntax Literate: Jurnal Ilmiah Indonesia, vol. 6, no. 2, pp. 949-959, Feb. 2021, doi: 10.36418/syntax-literate.v6i2.2194.

[17] Minsih, J. S. Nandang, and W. Kurniawan, 'Problematika Pembelajaran Online Bagi Anak Berkebutuhan Khusus Di Sekolah Dasar Masa Pandemi Covid-19', JURNAL BASICEDU Research \& Learning in Elementary Education, vol. 5, no. 3, pp. 1252-1258, 2021, doi: 10.31004/basicedu.v5i3.876.

[18] M. Sadeghi, 'A Shift from Classroom to Distance Learning: Advantages and Limitations', 2019, doi: 10.29252/ijree.4.1.80.

[19] P. Pannen, 'Distance education public policy and practice in the higher education: The Case of Indonesia.', $R B A A D$, vol. 2, May 2008, doi: 10.17143/rbaad.v2i0.128.

[20] A. Marabani and L. Moretti, 'Goldman and Siegel on the Epistemic Aims of Education. Journal of Philosophy of Education - Wiley Online Library', 2020. https://onlinelibrary.wiley.com/doi/full/10.1111/1467-9752.12398 (accessed Apr. 27, 2021).

[21] A. van Leeuwen and J. Janssen, 'A systematic review of teacher guidance during collaborative learning in primary and secondary education | Elsevier Enhanced Reader', 2019. https://reader.elsevier.com/reader/sd/pii/S1747938X18303403?token=67274689527030FA6B55B 37CB5C85B7ECDC451D1D64EF3D67646A65AD7E15BEDD47AA88C8204334296B015D3FF 684EAE\&originRegion=eu-west-1\&originCreation=20210427052416 (accessed Apr. 27, 2021).

[22] G. Magnússon and J. Rytzler, 'Approaching higher education with Didaktik: university teaching for intellectual emancipation', European Journal of Higher Education, vol. 9, no. 2, pp. 190-202, Apr. 2019, doi: 10.1080/21568235.2018.1515030.

[23] S. A. Asongu and N. M. Odhiambo, 'Basic formal education quality, information technology, and inclusive human development in sub-Saharan Africa', Sustainable Development, vol. 27, no. 3, pp. 419-428, May 2019, doi: 10.1002/sd.1914.

[24] S. Pirani and N. Hussain, 'Technology is a tool for Learning: Voices of Teachers and Parents of Young Children', J.educ.soc.sci, vol. 7, no. 1, pp. 55-66, Mar. 2019, doi: 10.20547/jess0711907105. 
[25] J. Webster and P. Hackley, 'Teaching Effectiveness in Technology-Mediated Distance Learning', $A M J$, vol. 40, no. 6, pp. 1282-1309, Dec. 1997, doi: 10.5465/257034.

[26] R. Erikson, 'Is it enough to be bright? Parental background, cognitive ability and educational attainment', European Societies, vol. 18, no. 2, pp. 117-135, Mar. 2016, doi: 10.1080/14616696.2016.1141306.

[27] N. E. Hill, D. P. Witherspoon, and D. Bartz, 'Parental involvement in education during middle school: Perspectives of ethnically diverse parents, teachers, and students', The Journal of Educational Research, vol. 111, no. 1, pp. 12-27, Jan. 2018, doi: 10.1080/00220671.2016.1190910. 